Pobrane z czasopisma Annales H - Oeconomia http://oeconomia.annales.umcs.pl Data: 26/04/2023 14:03:17

DOI:10.17951/h.2017.51.2.219

\begin{tabular}{lcl}
\hline & A N N A L E S \\
UNIVERSITATIS MARIAE CURIE-SKŁODOWSKA \\
LUBLIN - POLONIA \\
VOL.LI, 2 & SECTIOH H \\
\hline
\end{tabular}

Maria Curie-Skłodowska University in Lublin, Marketing Department

\author{
GENOWEFA SOBCZYK \\ gsobczyk@vp.pl
}

\title{
Determinants of Consumption and Consumer Behaviours in Poland in the Context of Globalization
}

Uwarunkowania konsumpcji i zachowań konsumenckich w Polsce w kontekście

procesu globalizacji

Key words: consumption; globalization; household

Słowa kluczowe: konsumpcja; globalizacja; gospodarstwo domowe

JEL codes: D12; M31

\section{Introduction}

Integration and globalization of economies and markets are the processes that influence the dynamics and quality of consumption in the $21^{\text {st }}$ century. These processes give a direction of changes in modern societies, standardize consumption patterns and consumers' purchasing behaviour. However, the possibilities, the pace and scope of these phenomena have significantly shaped economic development and economic prosperity of countries. Socio-economic conditions differ in individual countries and regions, affect the level and dynamics of consumption and the prospects of implementing the aspirations of the consumer society. Consumer purchasing behaviours and the implementation of their consumption needs are determined not only by economic but also social, cultural and psychological considerations. Economic development occurring at a rapid pace in many regions of the world, considered as emerging markets, has greatly expanded the size of modern consumer society. 
The aim of the article is to present new conditions of consumption on the Polish market in the context of globalization. The basic source was a review of the literature in the field of consumption and contemporary consumption patterns of households and available statistical sources for the years 2007-2015.

\section{Consumption's globalisation as a contemporary megatrend}

Identifying new risk factors and determinants of consumption one should firstly point to progressive integration and globalization processes. Globalization is a multidimensional process, covering all areas of the life of the society. There is a close relationship between consumption and economic integration, which is defined by Stiglitz as "tight integration of countries and people in the world, caused by a large reduction in the cost of transport and telecommunications, and the abolition of artificial barriers in the flow of goods, services, capital, knowledge and people from country to country" [Stiglitz 2006, p. 2]. Zorska lists several features of globalization as the integration of a growing number of economies, resulting in a global economic system with high correlation and significant impacts of activities undertaken even in distant countries [Zorska 1998, p. 20]. The author, like other authors, considers globalization to be a higher form of progressive, a long-term process of internationalization of economic activities.

Globalization is driven by market factors, cost savings, competitive and governmental factors [Yip 2004, p. 42]. The pace of globalization was accelerated by modern technologies and wide use of IT and telecommunication technologies, in virtually all areas of life. Among market determinants of globalization there is a growing international harmonization of consumer preferences and massive demand, which encourage manufacturers and retailers to organise large-scale production and marketing activities enabling worldwide sales. This is facilitated by the rapid development of fast means of communication and transport, the existence of global brands, the functioning of international distribution networks, global advertising, etc.

The sphere of production, distribution and consumption is subject to processes of globalization. According to Mazurek-Łopacińska, globalization of consumption is the process encompassing the dissemination of a range of products on the global market, leading to the unification of consumption patterns and consumer behaviour in different parts of the world [Mazurek-Łopacińska 2003, p. 33]. Bywalec notes that in this process the same or similar consumption patterns spread on a transnational scale and create a global consumer culture, which generally comes from the areas of Western Europe and the United States of America [Bywalec 2010, p. 207]. Important factors contributing to the process of consumption's globalization include [Dąbrowska et al. 2015, p. 8; Mróz 2013, p. 22]:

- the digital revolution as a motivating factor for purchasing, as it ignores the barriers of time and space; 
- mass production of many goods and services;

- freedom of movement of people and goods;

- expansion of international retail chains;

- globalization of media.

Consumption's globalization has been associated with the homogeneity of the needs of buyers in most countries, and consequently the process of unification of consumption patterns, its level and structure, i.e. homogenization in the socio-professional and spatial dimension. Giving the main features that distinguish a modern consumer from the late $20^{\text {th }}$-century consumer, Samli [2012, p. 5] notices a positive transformation (Table 1).

Table 1. Changes in the characteristics of consumers in the era of globalisation

\begin{tabular}{|l|l|}
\hline \multicolumn{1}{|c|}{ Consumer's features } & \multicolumn{1}{c|}{ Consumer's benefits } \\
\hline Consumers are more product-conscious & They know of many alternatives \\
\hline Consumers are well informed & They know where and what products are available \\
\hline Consumers are aware of quality & They know which products have high quality \\
\hline Consumers recognise global brands & They know global brands and prefer them \\
\hline Consumers have access to products in a global network & They can buy products from many sources \\
\hline Consumers expect quick delivery & They know they will receive the product fast \\
\hline
\end{tabular}

Source: Samli [2012, p. 5].

In fact, the process of consumption's globalization has many advantages, but also it is a threat to society. Globalization results in a gradual loss of national and regional differences in production and consumption. Transnational corporations take over markets with product innovations and a powerful promotion to boost demand and profits. They contribute to the strengthening consumerism trend and following the consumption patterns characteristic for the developed countries of the world.

In the process of consumption's globalization, patterns of consumption and consumer behaviour play important roles. There are three types of behaviour in relation to the pattern: assimilation (imitation); a search for a new pattern through imitation, but by distinguishing from the previous; distinction (Figure 1).

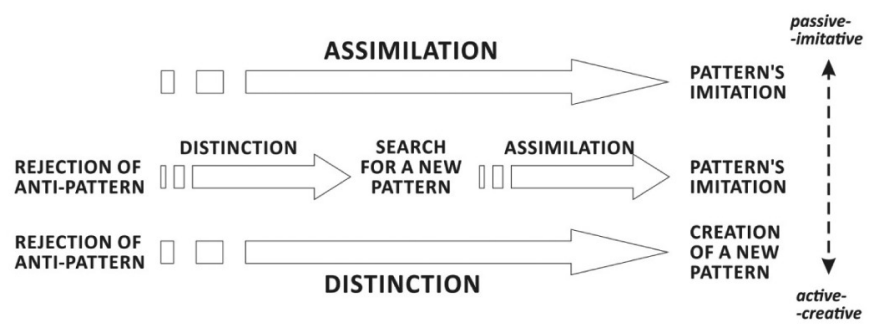

Figure 1. The use of patterns in consumption's globalisation 
Unification of consumption as a result of standardization of goods and services and their production on a massive scale has the widest range in markets. Homogenization of the market is facilitated by the distribution process through the creation of the international sales network of industrial and food products that are offered by global brands [Kłosiewicz-Górecka 2015, p. 139]. The second pattern of consumption and consumer behaviour shown in Figure 1 is created on the basis of a search for a new pattern resulting from combining global elements with local patterns. This forms the products which are recognized from global brands, but contain local values and the elements of local culture. This is a trend of consumption's hybridization or its glocalisation [Dąbrowska et al. 2015, p. 21; Bywalec 2010, p. 211].

The third type of consumer behaviour in the process of globalization is consumption distinguishing (heterogenising). As globalization has led to the massification of consumption, many consumers consciously aim at individualizing their purchasing preferences and lifestyles. Distinguishing by consumption requires a relatively greater activity and creativity of the consumer, compared to the imitation of a consumption pattern. The phenomenon of consumption's differentiation is intensified by increasing incomes, consumer ethnocentrism, psychographic characteristics of customers and the phenomenon of prosumption.

\section{Socio-economic determinants of consumption trends on the Polish market}

The process of globalization of consumption is associated with achieving a certain level of socio-economic development of a country. The main factors influencing consumption in the household sector at the macro level are demographic processes, conditions in the labour market, the value of gross domestic product, the level of taxation, growth in the prices of goods and services, inflation level, access to credit, etc. Currently, there exist trends in consumption and buyers behavioural patterns shape demographic and socio-educational changes, which include, in particular, the aging of the population, the fall in birth rates, the lengthening of life expectancy, the rise of the middle class, the growth in education, health education, the effect of imitation of lifestyle of reference groups, etc. They further form higher quality requirements on the part of consumers, as reported in relation to the offer of goods and services available on the market.

As presented in Table 2, the dynamics of key macroeconomic indicators in 2007-2015 was variable. It was associated with the effects of the global financial crisis in 2008. In the Polish economy, a marked deterioration in socio-economic situation took place as late as in 2009. An increase in economic activity took place in 2010, but results from the years 2011-2012 did not confirm avoiding the second wave of the crisis. Indicators characterizing the economic situation in the following years, especially in 2015, show an improvement in the economic situation. Situation on the labour market has improved due to an increase in employment and a fall in 
the unemployment rate down below $10 \%$. For the first time since 2005 , the number of the long-term unemployed decreased. The trigger of these favourable changes in the social situation was an increase in production and gross domestic product.

Table 2. The dynamics of basic macroeconomic factors in the Polish economy in 2007-2015

\begin{tabular}{|l|r|r|r|r|r|}
\hline \multirow{2}{*}{ Item } & \multicolumn{1}{c|}{2007} & \multicolumn{1}{c|}{2010} & \multicolumn{2}{c|}{2012} & \multicolumn{2}{c|}{2014} & 2015 \\
\cline { 2 - 5 } & \multicolumn{3}{|c|}{ Constant prices, previous year $=100$} \\
\hline Gross domestic product & 106.8 & 103.9 & 101.9 & 103.3 & 103.9 \\
\hline Sold industrial production & 111.2 & 109.0 & 100.8 & 104.1 & 106.0 \\
\hline Completed apartments to be sold (in thousands) & 116.5 & 85.0 & 116.8 & 101.2 & 103.4 \\
\hline Domestic demand & 108.7 & 104.6 & 99.8 & 104.9 & 103.4 \\
\hline Total consumption & 104.6 & 103.4 & 100.6 & 102.9 & 103.1 \\
\hline Private consumption in households (from private income) & 104.9 & 103.2 & 100.8 & 102.6 & 103.1 \\
\hline Retail sales & 107.6 & 99.0 & 102.3 & 103.9 & 105.4 \\
\hline Indicators of goods and services & 103.2 & 102.7 & 104.3 & 99.8 & 98.8 \\
\hline & \multicolumn{5}{|c|}{ Labour market indicators } \\
\hline Employed in thousands (as of 31 December) & 13,771 & 14,107 & 14,213 & 14,563 & 14,830 \\
\hline Registered unemployment \% (as of 31 December) & 11.2 & 12.4 & 13.4 & 11.4 & 9.8 \\
\hline Average monthly nominal gross income (previous year =100) & 107.9 & 103.9 & 103.5 & 103.2 & 103.5 \\
\hline Average monthly nominal real income (previous year =100) & 105.5 & 101.4 & 99.9 & 103.2 & 104.5 \\
\hline
\end{tabular}

Source: Statistical Yearbook of the Republic of Poland in 2009, 2012, 2016; Polish Statistical Yearbook for 2013 and 2016, GUS, Warsaw; Author's own calculations.

A primary factor affecting the level of consumption and determining the standard of living is the gross domestic product. GDP is closely linked to the level of the average monthly disposable income and disposable income attributable to one person in a household. Poland is gradually bridging the gap in living standards between itself and more developed countries of the European Union; a growth of GDP per capita at constant prices in 2007-2015 was increasing in year-to-year comparison, thus, ensured a continuous economic growth [Mały..., 2016, p. 395]. The value of Polish GDP per capita in the year of accession to the EU was less than $50 \%$, while at the end of 2014 it was $67.6 \%$. Higher incomes provide greater consumption opportunities, as well as more financial independence of a consumer.

The total category of income is disposable income, which determines the current and future consumption of individuals and households (private consumption). For the employed wages are a primary source of income, i.e. their real purchasing power. Average real gross monthly salary in 2009-2012 demonstrated a low growth, but since 2014 , its dynamics of growth has been significantly higher than in the previous period (Table 2). The average monthly disposable income per capita in Polish households was 1,386 PLN in 2015 , what was $49.3 \%$ higher in comparison to 2007 . The difference in income levels of farmers and self-employed has increased, while the disposable income of workers' households caught up with the average national income. After 2012, private consumption was supported by easier access to credits and loans, external assistance for the poorest, low inflation (deflation) and a decrease in savings. Since April 2016, "500+ Program" came into force to support families with more than one child. 


\section{Level and structure of consumption in households}

All income theories indicate that consumption follows the income of the buyer [Zalega 2012, p. 97]. Private consumption, calculated at current prices, increased between $2007-2015$ by $45.2 \%$, with a significant diversity of dynamics in individual groups of goods and services (Table 3). Dynamics of consumption was higher for services than for food. The highest growth was recorded for sales of transport services, which was associated with increases in fuel prices. A high increase in expenses also included health services, restaurants and hotels, and recreation and culture. In the group of industrial goods, a significant increase in consumption of household equipment and appliances, clothing and footwear was recorded. Considering a decline in the prices of goods and services from 2014 (Table 2), there is real growth in private consumption of goods and services.

The measure of the level of consumption encompasses the expenditure of households to purchase goods and services. As it is apparent from Table 3, over the considered period, not only an increase in consumer spending (monthly expenses per person in 2015) were higher (by $34.7 \%$ of the expenditures in 2007), but their structure changed to some extent. In the total expenditures the share of expenditures on food and non-alcoholic beverages decreased from $27.6 \%$ in 2007 to $24 \%$ in 2015 .

Table 3. Private consumption growth and structure of average monthly spending per person in households in Poland in 2007 and 2015

\begin{tabular}{|l|c|c|c|}
\hline \multirow{2}{*}{ Item } & $\begin{array}{c}\text { Growth of private } \\
\text { consumption } \\
\text { (in current prices, in \%) }\end{array}$ & \multicolumn{2}{c|}{$\begin{array}{c}\text { Structure of average monthly } \\
\text { expenditures per capita } \\
\text { (in \% of total expenditures) }\end{array}$} \\
\cline { 2 - 4 } & $2014: 2007$ & 2007 & 2015 \\
\hline Total in PLN in \% & 145 & 810 & 1,091 \\
\hline \multicolumn{1}{|c|}{ in \% } & & 100.0 & 100.0 \\
\hline $\begin{array}{l}\text { including consumer goods and } \\
\text { services in PLN }\end{array}$ & $\mathrm{x}$ & 776 & 1,032 \\
\hline \multicolumn{1}{|c|}{} & 121.4 & 95.8 & 95.6 \\
\hline Food and beverages & 151.4 & 27.6 & 24.0 \\
\hline Alcohol and tobacco & 161.3 & 2.8 & 2.5 \\
\hline Shoes and clothes & 135.5 & 5.8 & 5.4 \\
\hline Housing and energy & 163.8 & 19.1 & 20.1 \\
\hline Household equipment & 174.2 & 5.4 & 5.0 \\
\hline Health & 197.9 & 4.9 & 5.3 \\
\hline Transport & 111.7 & 9.6 & 8.8 \\
\hline Communication & 150.0 & 5.1 & 5.0 \\
\hline Leisure and culture & 116.9 & 7.7 & 6.7 \\
\hline Education & 165.9 & 1.3 & 1.0 \\
\hline Restaurants and hotels & 144.7 & 2.0 & 4.2 \\
\hline Other goods and services & & 5.3 & 5.9 \\
\hline Other & & 3.4 & 4.4 \\
\hline
\end{tabular}

Source: Statistical Yearbook of the Republic of Poland 2010; Polish Statistical Yearbook 2016, GUS, Warsaw; Author's own calculations. 
However, it is still higher than that of developed countries, where it is more than several percent. Another position in households expenditures is energy. The rate of $20.1 \%$ of total expenditure is similar to many Western European countries. Higher positions in the structure of expenditures of Polish households, in the comparable period, was occupied by expenditures on hotels and restaurants, and health. Whereas, the share of expenditures on educational services and on communications services decreased. Still, expenditures on basic needs (food and housing) are higher, and expenditures on services are lower than in the countries with a higher level of economic development.

A trend observed in the analysed period, is a relative de-consumption of food with an increase in the consumption of industrial goods and services. Changes in consumption include not only the quantitative side, but the quality of products consumed or used. In the group of food products, the products that increase nutritional value of diet, in particular processed dairy products (yogurt, cheese, butter, etc.), tropical fruits, juices and convenience products, saving time for preparing meals, gained importance [Świetlik 2015, p. 360]. In the significance scale, the consumption of cereal, potatoes and eggs was reduced in 2007-2015 [Rocznik..., 2008; Mały..., 2016]. The magnitude of changes in private consumption was associated with the characteristics of the household and its financial status.

Conditions for internationalization of markets facilitate distribution of modern durables among households, which displace the ones previously used. They include new generation electronic devices, computers with Internet access and cell phones. In $2015,78 \%$ of Polish households were equipped with computers and almost all had access to the Internet (76\%), while figures for the European Union amounted to 82 and $83 \%$, respectively [Rocznik..., 2016, p. 761]. Rapid spread of technologically advanced products is the source of consumption's modernisation, but also a factor aggravating globalization of consumption. Possession of modern durable goods and access to expensive services is a way to gain prestige and increase their value for some consumers.

\section{Conclusions}

The impact of external conditions on individual consumption in Poland in the post-accession period is evident and manifested by a wide range of industrial products, affordability of most goods, imitating western patterns and trends in consumption. The processes of globalization of consumption leads to imitating and creating global consumer culture and other forms of consumption in the $21^{\text {st }}$ century.

Changes in the level and structure of household consumption in Poland indicate a process of its modernization; the share of expenditures on food decreases while consumption of services and durable consumer goods increases. Consumption of equipment and electronic devices developed, which is a determinant of the modern lifestyle of their users. Differences in the possession of modern durable goods disappear between households with different income status. 


\section{Bibliography}

Burgiel, A., Spoleczne zjawiska w zachowaniach polskich konsumentów. Oddziatywania społeczne, naśladownictwo, ostentacja i snobizm, Wydawnictwo Uniwersytetu Ekonomicznego w Katowicach, Katowice 2014.

Bywalec, C., Konsumpcja a rozwój gospodarczy i społeczny, Wydawnictwo C.H. Beck, Warszawa 2010.

Dąbrowska, A., Bylok, F., Janoś-Kresło, M., Kiełczewski, D., Ozimek, I., Kompetencje konsumentów innowacyjne zachowania, zrównoważona konsumpcja, PWE, Warszawa 2015.

Kłosiewicz-Górecka, U., Handel detaliczny - zasoby, formaty i tendencje rozwoju, [in:] Handel wewnętrzny w Polsce 2010-2015, Instytut Badań Rynku, Konsumpcji i Koniunktur, Warszawa 2015.

Mały Rocznik Statystyczny Polski 2016, GUS, Warszawa.

Mazurek-Łopacińska, K., Zachowania nabywców i ich konsekwencje marketingowe, PWE, Warszawa 2003.

Mróz, B., Konsument w globalnej gospodarce. Trzy perspektywy, Oficyna Wydawnicza SGH, Warszawa 2013.

Roczniki Statystyczne RP za lata 2008-2016, GUS, Warszawa.

Samli, A.C., International Consumer Behavior in the $21^{\text {st }}$ Century: Impact on Marketing Strategy Development, Springer Science \& Business Media, New York 2012.

Stiglitz, J.E., Globalizacja, Wydawnictwo Naukowe PWN, Warszawa 2006.

Świetlik, K., Konsumpcja żywności w Polsce w minionej dekadzie. Uwarunkowania i tendencje, "Handel Wewnętrzny", no. 5, 2015, pp. 347-363.

Yip. G.S., Strategia globalna, PWE, Warszawa 2004.

Zalega, T., Konsumpcja. Determinanty, teorie, modele, PWE, Warszawa 2012.

Zorska, A., Ku globalizacji? Przemiany w korporacjach transnarodowych i gospodarce światowej, Wydawnictwo Naukowe PWN, Warszawa 1998.

\section{Determinants of Consumption and Consumer Behaviours in Poland in the Context of Globalization}

The paper presents changes in consumption in Polish households occurring in the context of internationalization and globalization of markets. The characteristics, forms and manifestations of consumption's globalization as well as socio-economic determinants of private consumption and their influence on the consumption of food products, industrial goods and services were presented. Available statistics of GUS (Central Statistical Office) were used as a source.

\section{Uwarunkowania konsumpcji i zachowań konsumenckich w Polsce w kontekście procesu globalizacji}

W artykule zaprezentowano zmiany w konsumpcji w sektorze polskich gospodarstw domowych, zachodzące w kontekście umiędzynarodowienia i globalizacji rynków. Wskazano na cechy, formy i przejawy globalizacji konsumpcji oraz uwarunkowania społeczno-ekonomiczne spożycia prywatnego i ich wpływ na kształtowanie się spożycia produktów żywnościowych, przemysłowych i usług. Wykorzystano źródła dostępnej statystyki GUS. 